\title{
BLACK FEMINISM INTERPRETATION IN MAYA ANGELO'S POEMS WITH FIGURATIVE LANGUAGE AND IMAGINARY ANALYSIS
}

\author{
Heni Alghaniy Maulidina \\ Muhammadiyah University of Bengkulu \\ email: hnimaulidina01@gmail.com
}

\begin{abstract}
Poetry is one type of literary work with characteristics that make it different from other literary works. Currently, there are many poems written using the experience of discrimination as an object due to various conditions appearing in society. Besides that, many female poets write poetry using a feminist approach. This study aimed to identify figurative language and images related to Maya Angelou in black feminism in her poetry. It also analyzes the influence of Maya Angelou's black feminist thought reflected in her poetry through figurative words and images. In this qualitative study, the authors use a descriptive method through several steps, preparation, data collection, and data analysis. This research focused on analyzing figurative language, types of images, and black feminism in Maya Angelo's poems. The figurative language and imagination used in the poems are diverse, such as metaphor, personification, paradox, symbol, irony, irony, visual imagery, and auditory imagery. In this analysis, it can be concluded that the black feminist movement is courageous, brave, and outspoken.
\end{abstract}

Keywords: black feminism, figurative language, imaginary, Maya Angelo, poems

\section{INTRODUCTION}

Literature is a beautiful work of art that comes from human life. According to Abrams, the term literature has been used since the 18th century as a signifier Fiction and imagination writings include poetry, prose, stories and drama. (2014). Literature represents language, culture and tradition. Literature work is the result of the expression of the author's feelings and imagination. The word literature comes from the Latin, literature, which means to write (Abrams, 2014).

Poetry is one type of literary work that has characteristics and characteristics makes it different from other literary works. Poetry is written in a way that different. Poetry is the result of human creativity which is poured through arrangement of words that have meaning. Language used in poetry also different. According to Wayne Shumaker (1965), poetry is an idea or thought poet who flows as a medium to express perceptions, feelings, and certain thoughts. Laurence Perrine (1969) said that poetry is universal language and the oldest rich in diction.

In this study, the writer chose poetry to be analyzed because poetry is one of the unique literary works that has more meaning and imagination than the reader thinks. Currently there are many poems written using the experience of discrimination as an object due to various conditions appearing in society. Besides that, there are also many female poets who writing poetry using a feminist approach. For example image women in society, the position of women among men, and various other discrimination that occurs in women's lives.

The history of feminism stems from the feminism of the western world because of the thought the beginning of the feminist movement was a reaction to discrimination against women in the western world. Hooks in his book Feminism is for Everybody: Passionate Politics (2000) provides a simple definition of feminism. According to Hooks, feminism is a movement to end sexism, exploitation sexual violence and oppression. 
According to Krolokke and Sorensen (2005), history Feminism is divided into three waves. Each wave has aspects-different aspects of the same feminist issues.

Maya Angelou or known as an AfricanAmerican woman influential in America. He was a great novelist and poet. Her poetry has become an inspiration for feminist movement fighters. Throughout the history of the women's movement, especially in the United States, there have been African-American women's movement. The writer wants to analyze some of Maya Angelou's poems that tell the history of African-American black women living among white Americans.

These poems are "When I Think About Myself” (1971), “Still I Rise” (1978), "Phenomenal Women" (1978), Caged Bird (1983) and "Equality" (2001). The reason why the writer chose Maya Angelou's poems is because his poetry shows the living conditions of African Americans through Maya Angelou's point of view. Another reason for choosing Maya Angelou's five poems is because the poems talk about women. The writer as a woman is interested in understanding how Angelou imagines women through his poetry. In addition, the author chooses black feminism because the movement has become an important political theory to know because it discusses the segregation and racism of black women who are injured in civil rights and the women's movement.

Problem Formulation are what types of figurative language and imagery are contained in Maya Angelou's poems? How is the thought of Maya Angelou's black feminism reflected in her poems through figurative language and imagery?

Research Purposes are identify the types of figurative language and imagery associated with black feminism Maya Angelou in her poems and analyzing the influence of Maya Angelou's black feminism thought which is reflected in her poems through figurative language and imagery.

The benefits of doing this research are divided into two categories, namely theoretical benefits and practical benefits. Theoretically, this research is expected to broaden the discussion in literary studies, especially regarding the black feminism movement. Practically, this research aims to change the perspective and reinterpret the world and social life. People have to come back to see the world in a balanced way which means they have to treat other human beings the same way. Therefore, it is hoped that people will contribute to the improvement of relations between men and women as well as community groups with different races.

This study focuses on the analysis of figurative language and imagery as well as the reflection of Maya Engelou's feminist thought in her three poems. The author uses the theory of Laurence Perrine in his book entitled Sound and Sense, an Introduction to Poetry (1969) to analyze the types of figurative language and imagery in poetry, then analyzes Maya Angelou's black feminism contained in her poems using Collin's theory in her book Black Feminist Thought (2000).

Poetry tends to play with words which is also often referred to as figurative language. There are many theories about figurative language from experts. Laurence Perrine (1969) states that figurative language is a way of expressing something with a different meaning. In other words, the use of figurative language is to describe something by saying something but having a different meaning in order to add a strong and new impression in terms of expression. In his book Perrine describes the types of figurative language

According to Abrams (2014) figurative language is a deviation from the use of language by speakers from the understanding of the language used in everyday life (ordinary), deviation from standard language, 
or deviation in the meaning of words, a deviation from a series of words in order to obtain some special meaning. Figurative or figurative language according to Abrams (2014) consists of simile (comparison), metaphor, metonymy, synecdoche, and personification. Meanwhile, Pradopo (2021) divides figurative language into seven types, namely comparison, metaphor, parable, epic, personification, metonymy, and allegory.

Imagery is one of the important elements in poetry to strengthen the imagination of the reader and bring the reader to understand more deeply the mind of the poet. This is very important because by understanding the mind of a poet or writer, poetry can be a means of communication between readers and writers. Imagery can be categorized as a representation of feelings through language (Perrine, 1969).

Images or images may be directly related to mental images, something that is seen through the mind, and visual images are the most frequent in poetry. However, an image can also represent sound (Auditory Imagery); fragrance (Oldfactory Imagery); taste (Gustatory Imagery); touch such as hardness or softness, wet or hot and cold (Tactile Imagery); internal sensations such as hunger, thirst, tiredness, or nausea (Organic Imagery); movements, tension in muscles and joints (Kinesthetic Imagery) (Perrine, 1969). In other words, imagery is language that directly touches feelings.

Feminism (the characters are called Feminists) is a women's movement which demands emancipation or equality and fairness of rights with men. Feminism unlike any other view or understanding. Feminism doesn't come from a theory or concept based on a single theoretical formula. According to William Outwaite, feminism is defined as advocacy or support for the equality of women and men, accompanied by with a commitment to improve the position of women in society. This term assumes that there are unequal conditions between men and women, both in the form of male domination (patriarchy), inequality gender, or the social effects of gender differences.

Nicholas Abercrombie et al. argues that feminism is an understanding that defending equal opportunity for men and women. Girl systematically weakened in modern society, feminism is a social movement that has gradually improved the position of women in western society. Women's issues formulated by feminist theories become three major parts of the theory, namely the first wave, second wave and third wave of feminism. Categorization of the three great waves of feminism was first carried out by Rosemarie Tong, a feminist who has produced books on feminism theory, among others his famous book is Feminist Thought (1990).

Black feminism is a part of feminism. The term feminism black is a more progressive vision of a defined society based on the historical and ongoing struggle of racial and sexual oppression experienced by black black women in their homes, workplaces, communities and even society as a whole. Black feminism theory evolves to address the mishandling of feminism in African-American women in the previous feminist movement. Collins (2002) argue that feminism has been interpreted as a movement for whites. Deep-seated racism in the feminist movement is a tool used by white women to remove black black women from the movement. Black feminism argues that sexism, class oppression, and racism are built together.

\section{METHODS}

In this qualitative research, the author uses a descriptive method through several steps as follows.

Preparation. In the first stage, the writer reads selected poems by Maya Angelou, namely "When I Think About Myself” (1971), "Still I Rise” (1978), 
"Phenomenal Woman" (1978), Caged Bird (1983), and "Equality" (2001). The author also reads several books and journals related to black feminism, namely Black Feminist Thought, and What's in the name? Womanism, Black feminism, and beyond from Patricia Hill Collins, Combahee River Collective in Home Girls by Barbara Smith. The author also reads the definitions and meanings of figurative and imagery from Laurence Perrine's book Sound and Sense, an Introduction to Poetry.

Data collection. The data were obtained in three selected poems by Maya Angelou. The author groups the figurative and imagery language contained in the three poems by Maya Angelou and explains the meaning contained in each of the poems.

Data analysis. The writer analyzes the poems and groups the figurative language and types of imagery contained in Maya Angelou's poetry. The author uses Perrine's theory in his book Sound and Sense, an Introduction to Poetry (1969) on figurative language and imagery as well as the theory of black feminism from Patricia Hill Collins' book Black Feminist Thought (2002) to find out how thoughts in the black feminist movement are reflected through figurative language and imagery in selected poems by Maya Angelou.

\section{FINDINGS AND DISCUSSION}

First, Figurative Language and Imagery in the Poetry "Still I Rise". Simile Figurative Language. Simile is a figurative language that compares one thing to another indirectly. By using comparison words such as like, as, than, similar to, or resembles. $1^{\text {st }}, 3^{\text {rd }}, 6^{\text {th }}, 8^{\text {th }}$ stanza.

But still, like dust, I'll rise.

(Angelo, 1994)

The sentence "But still, like dust, I'll rise" is used as a parable for describe the passion of his awakening. Angelou seemed to fly high like dust. Where the dust will fly higher and free if the wind blows, too with the life of an increasingly confident African American woman though continue to be ostracized.

Figurative Language Hyperbole. Hyperbole is figurative language that exaggerates something without detracts from reality from its true meaning.

$6^{\text {th }}$ stanza

You may shoot me with your words, You may cut me with your eyes, You may kill me with your hatefulness, But still, like air, I'll rise.

(Angelo, 1994)

Angelou wants to convey a message of hatred and contempt by the group majority of African Americans. He displays how the character they were killed. This is reflected in the diction in the sixth stanza. Repetition used by Angelou to show courage points despite being hurt time and time again they will still rise.

Gustatory imagery or tasteful images are images related to impressions or images produced by the sense of taste.

$1^{\text {st }}$ stanza

You may write me down in history

With your bitter twisted lies

(Angelo, 1994)

Motion Imagery (Kinaesthetic Imagery) is a picture of something that seems to be able to move.

$2^{\text {nd }}$ stanza

Cause I walk like I've got oil wells, Pumping in my living room

(Angelo, 1994)

Second, Figurative Language and Imagery in the Poetry "Phenomenal Woman". Metaphor Figurative Language. Metaphor is a figurative language that compares something with others directly and do not 
use connecting words. Angelou express strength and confidence as a black woman use metaphors. She confirmed that she was no longer a skin woman helpless black.

$2^{\text {nd }}$ stanza

Then they swarm around me, A hive of honey bees

(Angelo, 1994)

Angelou compares men to honey bees. Show that African American women are strong and can attract attention like honey. So many people are attracted by their unique beauty.

Figurative Language of Personification . Personification is figurative language that gives the character, behavior or human equipment to animals, objects, or concepts.

$3^{\text {rd }}$ stanza

The grace of my style

(Angelo, 1994)

Angelou prided himself and accepted himself and his body shape and his skin color though different from most people.

Visual images are images generated by the sense of sight (eye). Visual imagery is able to stimulate the senses sight so that things that are not seen become as if they are seen.

$1^{\text {st }}$ stanza

I'm not cute or build to suit a fashion model' size

(Angelo, 1994)

Auditory imagery is an image produced by mentioning or decipher the sound of the voice so that the reader seems to follow hear and imagine the author's words.

$4^{\text {th }}$ stanza

I don't shout or jump about

Or have to talk real loud

(Angelo, 1994)

Third, Figurative Language and Imagery in "Equality Poetry". Figurative Language of Symbols. Symbols can be interpreted as figurative language that emphasizes something has its own meaning beyond the actual meaning.

\section{$2^{\text {nd }}$ stanza}

While my drums beat out the message and the rhythms never change

(Angelo, 1994)

The drum is a symbol in this poem that represents the instrument writers to express their feelings as contained in poetry, books and speeches, where the contents of the instrument never change, namely about women who are asking for their rights back.

Sinedoke Figurative Language. Sinedoke is the use of the same word as fact whose purpose clarify.

$2^{\text {nd }}$ stanza

We have lived a painful history

We know the shameful past

(Angelo, 1994)

Angelou wanted to explain to the world about their past that darkened by the slavery they endured for centuries.

Auditory imagery is an image produced by mentioning or decipher the sound of the voice so that the reader seems to follow hear and imagine the author's words.

$3^{\text {rd }}$ stanza

Hear the tempo so compeling

Hear the blood throb through my veins

Yes, my drums are beating nightly

And the rhythms never change

(Angelo, 1994)

Feeling images (organic imagery) are images related to personal experiencing body, including sensations such as hunger, scorching, and the emotions of tiredness, pain, and fed up.

$2^{\text {nd }}$ stanza

We have lived a painful history,

We know the shameful past,

(Angelo, 1994) 
Fourth, Figurative Language and Imagery Caged bird. Metaphore Figurative Language. Metaphor is a figurative language that compares something with other directly and do not use connecting words.

$1^{\text {st }}$ Stanza

A free bird leaps on the back

Of the wind and floats downstream

Till the current ends and dips his wing

In the orange suns rays

And dares to claim the sky

(Angelo, 1983)

She is referring to nature. She describes how "a free bird leaps behind a wind." She describes a bird's flight in an orange sky. A free bird has a "right to claim the sky." The way she describes "orange sun rays" gives readers an appreciation of the natural beauty of the sky, and the way birds "soak their wings" description helps readers evaluate birds in their natural habitat.

Feeling images are images related to personal experiencing body, including sensations such as hunger, scorching, and the emotions of tiredness, pain, and fed up.

Stanza 2

But a BIRD that stalks down his narrow cage

Can seldom see through his bars of rage His wings are clipped and his feet are tied

So he opens his throat to sing.

(Angelou, 1971)

Fifth, Figurative Language and Imagery When I Think About Myself. Paradox Figurative Language. The paradox is a metaphorical expression in which statements appear to be inconsistent in their own right. These types of statements can be described as paradoxical. However, a compressed paradox composed of several words is called an oxymoron.

Stanza 1

When I think about myself,
I almost laugh myself to death, My life has been one great big joke, A dance that's walked

A song that's spoke, I laugh so hard I almost choke When I think about myself.

(Angelou, 1971)

In the first verse of "When I Think About Myself," the story begins with the time that came to be used as the title of the post poem. It is a refrain, and it reappears at the end of the first and second verses. When the narrator thinks about his life, it is later compared to dancing and singing, but it feels like a kind of "joking". She can't stop laughing when she sees what she's done. She almost laughed "until she died."

Auditory imagery is an image produced by mentioning or decipher the sound of the voice so that the reader seems to follow hear and imagine the author's words.

Stanza 3

My folks can make me split my side, I laughed so hard I nearly died,

The tales they tell, sound just like lying, They grow the fruit,

But eat the rind,

I laugh until I start to crying,

When I think about my folks.

(Angelou, 1971)

\section{CONCLUSION}

Reflections on the idea of black feminism in three poems by Maya Angelou focused on the messages that appear in these poems through use of figurative language and imagery. In this chapter, the author discusses about how the image of black women in America is reflected in the works of poetry Maya Angelou and what messages Maya Angelou displays as an African-American woman who struggles with discrimination. Slavery that occurs in America can be categorized as racism that triggered by economic factors. The history 
of slavery, as a black chapter of American history.

Through messages that emerge from figurative language and imagery, it is found also the thoughts of black feminism which are reflected in the three poems by The Maya Angelou. In the poem "Still I Rise" there are thoughts black feminism depicting African-American women who courageous and eager to rise above the discrimination of the white American majority. They want to show the world that they are amazing, strong, and cannot be underestimated. In the poem "Phenomenal Woman" found also black feminist thought that sends a message about African American woman who is confident and trying to break beauty standards in society.

In the poem "Equality" there is a message about strong and courageous women in fighting for their freedom and the group. They want to be equal and accept their rights as human beings and must be released from the shackles of discrimination they have experienced for so long centuries.In the poem "Caged Bird" there is a message about discrimination and racism made her cage and she sang, but her voice was inaudible in the wider world and felt only to the person closest to her cage. In the poem "When I Think About Myself" there is a message about oppression and life. She does not mention it directly, but alludes to the repressed nature of her life and the lives of her people.

\section{REFERENCES}

Abrams, M. H. (2014). A glossary of literary terms. Cengage Learning.
Angelou, M. (2013). The complete collected poems. Hachette UK.

Anggiamurni, A. N. (2020). An analysis of figurative language in poetry by Maya Angelou. PANYONARA: Journal of English Education, 2(2), 149-160.

Bouras, C. B., \& Lobna, M. (2018). Analyzing the aspects of racism in the American postmodern feminist poetry (The poem" Still I Rise" as a case of study) (Dissertation). Faculty of Arts and Languages Department of Arts and English Language Echahid Hamma Lakhdar University, Algeria. Collins, P. H. (2002). Black feminist thought: Knowledge, consciousness, and the politics of empowerment. Routledge.

Halim, F. K. (2017). Types and the roles of feminism in the Angelou's selected poems (Doctoral dissertation) Universitas Islam Negeri Alauddin, Makassar. Isti' anah, A. (2017). Stylistic analysis of Maya Angelou's equality. Lingua, 11(2), 85-89.

Palupi, N. R. (2014). The sounds of African-American in Maya Angelou's poems: Alone, still i rise, caged bird and equality. Jurnal Ilmiah Mahasiswa FIB, 7(4).

Perrine, L. (1969). Sound and sense, an introduction to poetry ( $3^{\text {rd }} \mathrm{ed}$.). Orlando, Harcourt Brance: Collage Publisher.

Pradopo, R. D. (2021). Beberapa teori sastra metode kritik dan penerapannya. UGM PRESS. Suhadi, A., Baluqiah, K., \& Mariansyah, Y. (2016, November). The comparative analysis of feminism thought in poems of Maya Angelou and Audre Lordre. In Ninth International Conference on Applied Linguistics (CONAPLIN 9). 